\title{
Green and sustainable membrane fabrication development
}

\author{
Alaa Mohamed ${ }^{1}$, Samy Yousef ${ }^{2}$ \\ ${ }^{1}$ Department of Mechatronics, Canadian International College, Fifth Settlement, New Cairo, Egypt \\ ${ }^{2}$ Department of Production Engineering, Faculty of Mechanical Engineering and Design, University of \\ Technology, LT-51424 Kaunas, Lithuania \\ ${ }^{2}$ Department of Materials Science, South Ural State University, \\ Lenin prospect 76, 454080, Chelyabinsk, Russia \\ ${ }^{1}$ Corresponding author \\ E-mail: ${ }^{1}$ alakha@kth.se, ${ }^{2}$ ahmed.saed@ktu.lt
}

Received 23 May 2021; received in revised form 23 June 2021; accepted 29 June 2021 DOI https://doi.org/10.21595/stge.2021.22126

Check for updates

Copyright (C) 2021 Alaa Mohamed, et al. This is an open access article distributed under the Creative Commons Attribution License, which permits unrestricted use, distribution, and reproduction in any medium, provided the original work is properly cited.

\begin{abstract}
To meet the present demands of environmental protection, resource efficiency, and specific separation under severe conditions, continued research and enhancement of membrane technology is necessary. One of the major innovations for improving the sustainability of separation processes has been the use of green solvents for membrane preparation. In this regard, environmentally friendly methods and preparation techniques for high-performance membranes have recently been developed. This article gives an overview of current advancements in polymeric membrane manufacturing processes in terms of environmental preservation and health safety.
\end{abstract}

Keywords: green solvents, membranes, phase inversion, sustainability, water treatment, environmental-friendly polymers.

\section{Introduction}

The basis for sustainable development in any civilization are energy supply, drinkable water availability, raw material depletion, and environmental protection. Potable water production has become a global problem; for many places, anticipated population increase and accompanying demand exceed existing water supplies. A substantial portion of the world's population does not have access to safe drinking water or sanitation, which is a major cause of disease and a barrier to long-term development. Indeed, all economies, regardless of size, rely on the sustained availability of clean water supplies. Energy consumption has increased dramatically in recent decades, and the treatment and reuse of generated water, as well as the creation of water through desalination, all require energy. Water production requires energy at many stages, from water intake through freshwater separation and delivery.

The advancement of waste reduction, energy recovery, recycling, and capital cost reduction has envisioned a more sustainable green future [1, 2]. Membrane-based technology offers an appealing alternative to conventional separation procedures for achieving this goal [3]. Membrane technology, also known as popular separation technology, has long been a popular industrial method for several decades due to its low energy consumption, easy operation, simple and efficient equipment, small space requirement, and high separation performance [4-6]. The inherent properties of the membrane such as selective separation, continuous operation, no extra chemicals, energy conservation, simple scaling and process, can provide desired results without the disadvantages of conventional methods [7,8]. Membranes are used in a variety of sectors, including water treatment, pharmaceutical, food, medical, and biotech. The origin and characteristics of treated streams, as well as the final separation aim, influence the process type and membrane material chosen. Microfiltration, ultrafiltration, nanofiltration, reverse osmosis and are the primary membrane technologies that can be considered for purifying applications $[2,8]$.

Chemical processes must be developed with the objective of decreasing or eliminating the 
usage of hazardous compounds and at the same time meeting today's needs without endangering future generations' capacity to meet their own needs. [9]. Due to their ability to behave as inert fluids and dissolve the specified solute, chemical processes are inextricably linked with the usage of a broad range of solvents. The importance of solvents is demonstrated by their market, which is evaluated to be in the millions of tonnes per year $[10,11]$. The widespread usage of solvents, along with a greater understanding of chemical characteristics, has resulted in a re-evaluation of the commonly used solvents throughout the globe, as well as the quest for new greener alternatives for instantaneous/progressive replacement $[12,13]$. The European Commission is interested in less-toxic or non-toxic solvents, with instructions targeted at preserving human health and the environment [14, 15]. Furthermore, combined with the economic element, the social and environmental factors are essential foundations for attaining sustainability [16].

Since the advantages of a more sustainable and greener preparation process are immeasurable, the best option for replacing hazardous solvents without compromising membrane performance is based on its good toxicological profile and specific physical properties, such as complete solubility in water, high boiling point, and low molecular weight. The purpose of this article is to highlight scientists' and researchers' attempts to create more environmentally friendly polymeric membrane production processes by develop and implement a greener synthesis pathway, and chemical processes that gradually become greener and more sustainable to prevent environmental consequences. In addition, in order to accomplish substantial improvements in membrane formation, provide some potential recommendations, past approaches, and future research prospects.

\section{Sustainable membrane solvents}

\subsection{Recent advances for green and sustainable Membrane fabrication}

MF and UF have grown into the comprehensive solution for removing suspended particles, emulsions, colloids, and microorganisms from virtually any water source, including fresh, saline, process, and wastewater, over the last two decades [17]. MF is commonly used to separate small particles with a diameter of $0.1-10 \mathrm{~m}$ and to reject microorganisms from water [18]. UF membrane has smaller hole diameters, ranging from 0.001 to $0.10 \mathrm{~m} \mathrm{[19].} \mathrm{The} \mathrm{desire} \mathrm{for} \mathrm{highly} \mathrm{chemically,}$ thermally, and mechanically robust membranes with low fouling propensity remains a major aim for the membrane industry. Improvements in the preparation method and membrane material selection, including the discovery of novel materials, are critical in ensuring the long-term viability of membrane technology [20].

The ability of PES and PVDF to dissolve in common organic solvents makes them attractive for generating porous membranes using phase immersion techniques [7]. Despite various efforts to develop high-performance membranes, only a few studies have focused on developing a more prospective membrane preparation procedure, and most the companies continue to use conventional organic solvents such as N-Methyl-2-pyrrolidone (NMP) and N, N-dimethyl acetamide (DMA) [21]. The final point is critical when considering that the solvent constitutes the majority of the mass and component during membrane construction. Furthermore, the vast majority of the organic solvents utilized in the manufacture of membranes have been recognized as extremely hazardous to human health and the environment [22]. The chosen solvent plays an important role in the membrane preparation process, influencing the polymer precipitation rate and, as a result, affecting the final membrane shape and characteristics.

The environmental consequences of membrane preparation are becoming increasingly serious as more applications rely on membrane technology [23]. Solvents play an important role in membrane production, and the characteristics of a solvent and how it interacts with the polymer impact membrane shape and therefore performance [24]. As a result, finding a green solvent capable of dissolving the polymer of interest is only a first step; the resultant membrane must also function well in order to be embraced by the membrane industry. Furthermore, hazardous solvents 
are no longer allowed to be used in membrane manufacturing due to environmental laws. DMF, DMAc, and NMP, for example, have been designated as chemicals of very high concern by the European Registration, Evaluation, Authorization, and Restriction of Chemicals (REACH), and their usage will be banned beyond May 2020 [23]. Table 1 summarizes recent research on green solvent options for membrane manufacturing.

Organic compounds derived from petroleum products are frequently used as solvents in the chemical industry, posing health and environmental concerns. Without a doubt, substituting water for organic solvents has significant advantages. Hanafia et al. [25] described the creation of a porous membrane from hydroxypropyl cellulose, a water-soluble biopolymer (HPC). To fix the membrane shape and avoid resolubilization, HPC was first dissolved in water at a concentration of 20 , and then a $0.5 \mathrm{wt} . \%$ glutaraldehyde crosslinker was added in a dope solution after degassing. A catalyst of $1 \mathrm{wt} . \% \mathrm{HCl}$ was introduced just before casting the membrane to start the crosslinking reaction. Chemical crosslinking was used to test membrane stability in a variety of organic solvents (DMSO, tetrahydrofuran (THF), methanol, and chloroform).

$\gamma$-Valerolactone (GVL) is primarily a solvent with a low melting point and a high flash point; it has a distinct herbal odor, and it has lately been utilized in the taste, fragrance, and food sectors [26]. Vankelecom et al. [27] used GVL and a series of glycerol derivatives to produce porous membranes through NIPS with common polymers (PI, PES, polysulfone (PSU), cellulose acetate (CA), and cellulose triacetate (CTA) with the goal of researching bio-based green solvents in membrane preparation. ,'-diglycerol, glycerol, monoacetin, glycerol carbonate, and diacetin were the bio-based cosolvents used. By raising the dope polymer concentration, the researchers were able to effectively produce microfiltration (MF), ultrafiltration (UF), and potentially nanofiltration (NF) membranes.

The bio-based dihydrolevoglucosenone (Cyrene) is one of the developing green solvents for substituting polar aprotic solvents (e.g., NMP, DMAc, and DMF) [28]. Cyrene is a nontoxic solvent produced from renewable waste and a nonfood cellulosic source. Clark et al. [29] utilized cyrene to make PES flat sheet membranes for water filtration using the NIPS method, using polyvinylpyrrolidone (PVP) as an addition. The membranes produced with Cyrene and NMP were compared extensively. Membranes made using bio-based Cyrene had reduced polymer loss, adjustable pore diameters, and contact angles, and were more durable [24]. In comparison to NMP-fabricated membranes, the authors stated that Cyrene-fabricated membranes had higher overall porosity and bigger pore diameters. The permeability of membranes produced with Cyrene was readily adjusted in the region between $\mathrm{NF} / \mathrm{RO}$ and $\mathrm{MF}$ applications by altering the temperature of the dope solution, which influences the viscosity of the dope solution.

Sherwood et al. [28] found that cyrene may be made from biomass in two easy stages, reducing environmental impacts. Figoli et al. [2] used Cyrene in the fabrication of PES and PVDF membranes by phase inversion, where the membranes were produced using simultaneous VIPS and NIPS techniques. To get membranes with various pore diameters and permeability, the exposure period to ambient relative humidity was varied between 0 and 5 minutes in this study. Membranes manufactured using NIPS $(23,400 \mathrm{~L} / \mathrm{m} 2 / \mathrm{h} / \mathrm{bar})$ and VIPS-NIPS $(18,700 \mathrm{~L} / \mathrm{m} 2 / \mathrm{h} / \mathrm{bar})$ showed encouraging results in pure water permeability testing. The results showed that Cyrene may be utilized as a solvent for two of the most commonly used membrane polymers. The experimental findings were also reviewed in terms of dope solution viscosity, membrane shape, porosity, thickness, and contact angle.

More recently, Lee and Drioli et al. [30] proposed Polarclean as a promising eco-friendly option to replace polar aprotic solvents (e.g., NMP, DMAc, and DMF) for membrane preparation. The solvent is known by its IUPAC designation of methyl-5-(dimethylamino)-2-methyl-5oxopentanoate and has a high solvent power and moderate volatility. Polarclean has been used in cold solutions as a solvent for agrochemicals and as a crystal growth inhibitor. Furthermore, at $24{ }^{\circ} \mathrm{C}$, its solubility in water is quite high, at $490 \mathrm{~g} / \mathrm{dm}^{3}$. Wang et al. [31] used the Polarclean solvent as an NIPS solvent to produce PI, CA, PES, and PSU membranes. The experiment demonstrated that MF, UF, NF, and gas separation membranes may be made, demonstrating the 
Polarclean solvent's flexibility. Porous PES membranes with high pure water permeability were successfully manufactured in another study by Marino et al. [32]. Utilizing PolarClean as the solvent, the prepared membranes were produced using a combination of NIPS and VIPS techniques. The shape of the membrane was altered by common additions such as PVP and poly(ethylene glycol) (PEG).

The TIPS technique was used by Chaouachi et al. to manufacture membranes from recycled low-density polyethylene (LDPE) using butyl acetate as a greener solvent [33]. LDPE is a semi-crystalline polymer that is only soluble in hazardous chemical solvents such phthalate-based compounds at high temperatures. To test the differences, the scientists used xylene as a solvent, and the findings showed that the membrane produced using butyl acetate had ideal qualities in terms of thickness $(0.363 \mathrm{~mm})$, pore size $(0.14 \mathrm{~m})$, and contact angle $\left(120^{\circ}\right)$. Because the polymer was derived from recyclable materials, the findings were positive. Because the TIPS method works at higher temperatures (greater polymer solubility), there are more options for finding green solvents. Acetyl tributyl citrate (ATBC), for example, is a relatively new green solvent that has no health risks. ATBC has been documented and is commonly utilized in pharmaceutical coatings and food packaging [34]. ATBC is not water miscible, thus it is thought to be far more ecologically friendly than phthalate-based TIPS solvents. A PVDF membrane with competitive performance was created using ATBC. To maximize the mechanical strength of the membranes, up to $50 \mathrm{wt}$. $\%$ of polymer concentration was employed, and the produced membrane was then stretched to increase porosity and permeability.

Table 1. Potential green solvents for membrane preparation

\begin{tabular}{|c|c|c|c|c|}
\hline Solvent & $\begin{array}{l}\text { Solubility } \\
\text { (Water) }\end{array}$ & $\begin{array}{c}\text { Boiling } \\
\text { point }\left({ }^{\circ} \mathrm{C}\right)\end{array}$ & Polymer & Refs. \\
\hline Water & & 100 & HPC & {$[25]$} \\
\hline$\gamma$-Valerolactone (GVL) & - & 205 & $\begin{array}{l}\text { PI, PES, CA, CTA, } \\
\text { PSU }\end{array}$ & {$[27]$} \\
\hline Acetyl tributyl citrate (ATBC) & $\begin{array}{l}\text { Slightly } \\
\text { miscible }\end{array}$ & 331 & PES & {$[34]$} \\
\hline Triethyl phosphate (TEP) & Miscible & $215-216$ & $\begin{array}{l}\text { PVDF, CA, } \\
\text { PVDF/P(MMA- } \\
\text { rPEGMA) }\end{array}$ & {$[35-47]$} \\
\hline Gamma-butyrolactone (GBL) & Miscible & $204-205$ & PES & {$[48]$} \\
\hline Dimethyl sulfoxide (DMSO) & Miscible & 189 & PAN, PLA & $\begin{array}{c}{[2,41,45,49-} \\
57]\end{array}$ \\
\hline $\begin{array}{l}\text { 1-ethyl-3-methylimidazolium acetate } \\
\text { ([EMIM]OAc) }\end{array}$ & - & - & CA, PAN & {$[50,58]$} \\
\hline $\begin{array}{l}\text { 1-ethyl-3-methylimidazolium } \\
\text { thiocyanate ([EMIM]SCN) }\end{array}$ & - & - & $\mathrm{CA}$ & {$[58,59]$} \\
\hline $\begin{array}{l}\text { 1-ethyl-3-ethylimidazolium } \\
\text { dimethylphosphate ([EMIM]DEP) }\end{array}$ & Miscible & - & PES & {$[60,61]$} \\
\hline $\begin{array}{l}\text { 1,3-dimethylimidazolium dimethyl } \\
\text { phosphate ([MMIM]DMP) }\end{array}$ & Miscible & - & PES & {$[61]$} \\
\hline $\begin{array}{l}\text { Diethylene glycol monoethyl ether } \\
\text { acetate (DCAC) }\end{array}$ & Miscible & $218-219$ & PVDF & {$[62]$} \\
\hline
\end{tabular}




\begin{tabular}{|c|c|c|c|c|}
\hline Glycerol triacetate (TRIACETIN) & $\begin{array}{c}\text { Slightly } \\
\text { miscible }\end{array}$ & 258 & PVDF & {$[63]$} \\
\hline Triethylene glycol diacetate (TEGDA) & Miscible & 286 & PVDF & {$[64]$} \\
\hline Acetyl triethyl citrate (ATEC) & $\begin{array}{c}\text { Partially } \\
\text { miscible }\end{array}$ & $228-229$ & PVDF & {$[65]$} \\
\hline Triethyl citrate (TEC) & Miscible & 294 & PVDF & {$[65]$} \\
\hline $\begin{array}{c}\text { methyl-5-(dimethylamino)-2-methyl- } \\
\text { 5-oxopentanoate (Polarclean) }\end{array}$ & Miscible & $278-282$ & PVDF, PI, CA & {$[32,66-69]$} \\
\hline Maleic acid dibutyl ester (DBM) & Not miscible & 281 & PVDF & {$[70]$} \\
\hline Dibutyl sebacate & Not miscible & $178-179$ & PES & {$[71]$} \\
\hline Propylene carbonate & Miscible & 240 & PVDF & {$[71]$} \\
\hline$\gamma$-Butyrolactone ( $\gamma$-BL) & Miscible & $204-205$ & PVDF & {$[71]$} \\
\hline $\begin{array}{c}\text { 1-butyl-3-methylimidazolium } \\
\text { hexafluorophosphate ([BMIM][PF6]) }\end{array}$ & Miscible & 340 & PES & {$[72]$} \\
\hline Methyl lactate & - & 144 & $\begin{array}{c}\text { CA, cellulose } \\
\text { derivatives }\end{array}$ & {$[27,68]$} \\
\hline Ethyl lactate & - & 154 & CA & {$[73]$} \\
\hline Cyrene & - & 226 & PES, PVDF & {$[2,28,66]$} \\
\hline Ionic Liquids (ILs) & - & PAN, Cellulose, & {$[74,75]$} \\
\hline
\end{tabular}

\section{Conclusions}

Improving the long-term viability of membrane manufacturing is a critical topic in membrane technology that requires greater work and attention. The use of popular polar aprotic solvents (DMF, NMP, and DMAc) will be prohibited in May 2020, which is perhaps the most serious issue. Although membrane technology has a wide variety of applications, we concentrated on the long-term viability of solvents, particularly polymeric membranes. Many of the studies included in this study focused on discovering greener alternatives. However, numerous greener manufacturing procedures that reduce fabrication mass intensity have lately been described.

\section{References}

[1] R. A. Sheldon, "The E factor 25 years on: the rise of green chemistry and sustainability," Green Chemistry, Vol. 19, No. 1, pp. 18-43, 2017, https://doi.org/10.1039/c6gc02157c

[2] T. Marino, F. Galiano, A. Molino, and A. Figoli, "New frontiers in sustainable membrane preparation: Cyrene $^{\mathrm{TM}}$ as green bioderived solvent," Journal of Membrane Science, Vol. 580, pp. 224-234, Jun. 2019, https://doi.org/10.1016/j.memsci.2019.03.034

[3] S. Yousef, J. Šereika, A. Tonkonogovas, T. Hashem, and A. Mohamed, "CO2/CH4, CO2/N2 and $\mathrm{CO} 2 / \mathrm{H} 2$ selectivity performance of PES membranes under high pressure and temperature for biogas upgrading systems," Environmental Technology and Innovation, Vol. 21, p. 101339, Feb. 2021, https://doi.org/10.1016/j.eti.2020.101339

[4] M. F. Haase, H. Jeon, N. Hough, J. H. Kim, K. J. Stebe, and D. Lee, "Multifunctional nanocomposite hollow fiber membranes by solvent transfer induced phase separation," Nature Communications, Vol. 8, No. 1, pp. 1-7, Dec. 2017, https://doi.org/10.1038/s41467-017-01409-3 
[5] Z. Tan, S. Chen, X. Peng, L. Zhang, and C. Gao, "Polyamide membranes with nanoscale Turing structures for water purification," Science, Vol. 360, No. 6388, pp. 518-521, May 2018, https://doi.org/10.1126/science.aar6308

[6] A. Mohamed, S. Yousef, T. Hashem, and M. A. Abdelnaby, "Microstructure and modeling of uniaxial mechanical properties of Polyethersulfone nanocomposite ultrafiltration membranes," International Journal of Mechanical Sciences, Vol. 204, p. 106568, Aug. 2021, https://doi.org/10.1016/j.ijmecsci.2021.106568

[7] A. Figoli, T. Marino, and F. Galiano, "Polymeric membranes in biorefinery," in Membrane Technologies for Biorefining, Elsevier, 2016, pp. 29-59, https://doi.org/10.1016/b978-0-08-1004517.00002-5

[8] "Overview of membrane science and technology," in Membrane Technology and Applications, Chichester, UK: John Wiley \& Sons, Ltd, 2004, pp. 1-14, https://doi.org/10.1002/0470020393.ch1

[9] R. A. Sheldon, "Green and sustainable manufacture of chemicals from biomass: state of the art," Green Chem., Vol. 16, No. 3, pp. 950-963, 2014, https://doi.org/10.1039/c3gc41935e

[10] F. Pena-Pereira, A. Kloskowski, and J. Namieśnik, "Perspectives on the replacement of harmful organic solvents in analytical methodologies: a framework toward the implementation of a generation of eco-friendly alternatives," Green Chemistry, Vol. 17, No. 7, pp. 3687-3705, 2015, https://doi.org/10.1039/c5gc00611b

[11] X. Dong, D. Lu, T. A. L. Harris, and I. C. Escobar, "Polymers and solvents used in membrane fabrication: a review focusing on sustainable membrane development," Membranes, Vol. 11, No. 5, p. 309, Apr. 2021, https://doi.org/10.3390/membranes 11050309

[12] X. Dong, H. D. Shannon, C. Parker, S. de Jesus, and I. C. Escobar, "Comparison of two low-hazard organic solvents as individual and cosolvents for the fabrication of polysulfone membranes," AIChE Journal, Vol. 66, No. 1, p. e16790, Jan. 2020, https://doi.org/10.1002/aic.16790

[13] X. Dong, H. D. Shannon, and I. C. Escobar, "Investigation of PolarClean and Gamma-Valerolactone as solvents for polysulfone membrane fabrication," in Green Polymer Chemistry: New Products, Processes, and Applications, Vol. 1310, Washington, DC: American Chemical Society, 2018, pp. 385403, https://doi.org/10.1021/bk-2018-1310.ch024

[14] J. Da Silva Burgal, L. Peeva, and A. Livingston, "Towards improved membrane production: using low-toxicity solvents for the preparation of PEEK nanofiltration membranes," Green Chemistry, Vol. 18, No. 8, pp. 2374-2384, 2016, https://doi.org/10.1039/c5gc02546j

[15] M. Cvjetko Bubalo, S. Vidović, I. Radojčić Redovniković, and S. Jokić, "Green solvents for green technologies," Journal of Chemical Technology and Biotechnology, Vol. 90, No. 9, pp. 1631-1639, Sep. 2015, https://doi.org/10.1002/jctb.4668

[16] C. J. Clarke, W.-C. Tu, O. Levers, A. Bröhl, and J. P. Hallett, "Green and Sustainable Solvents in Chemical Processes," Chemical Reviews, Vol. 118, No. 2, pp. 747-800, Jan. 2018, https://doi.org/10.1021/acs.chemrev.7b00571

[17] P. Pal, "Introduction to membrane-based technology applications," in Membrane-Based Technologies for Environmental Pollution Control, Elsevier, 2020, pp. 71-100, https://doi.org/10.1016/b978-0-12819455-3.00002-9

[18] B. van der Bruggen, C. Vandecasteele, T. van Gestel, W. Doyen, and R. Leysen, "A review of pressuredriven membrane processes in wastewater treatment and drinking water production," Environmental Progress, Vol. 22, No. 1, pp. 46-56, Apr. 2003, https://doi.org/10.1002/ep.670220116

[19] M. M. Pendergast and E. M. V. Hoek, "A review of water treatment membrane nanotechnologies," Energy and Environmental Science, Vol. 4, No. 6, p. 1946, 2011, https://doi.org/10.1039/c0ee00541j

[20] F. Galiano, K. Briceño, T. Marino, A. Molino, K. V. Christensen, and A. Figoli, "Advances in biopolymer-based membrane preparation and applications," Journal of Membrane Science, Vol. 564, pp. 562-586, Oct. 2018, https://doi.org/10.1016/j.memsci.2018.07.059

[21] A. Figoli, T. Marino, F. Galiano, S. S. Dorraji, E. Di Nicolò, and T. He, "Sustainable route in preparation of polymeric membranes," in Green Chemistry and Sustainable Technology, Singapore: Springer Singapore, 2017, pp. 97-120, https://doi.org/10.1007/978-981-10-5623-9_4

[22] A. Figoli et al., "Towards non-toxic solvents for membrane preparation: a review," Green Chemistry, Vol. 16, No. 9, p. 4034, 2014, https://doi.org/10.1039/c4gc00613e

[23] X. Dong et al., "Eco-friendly solvents and their mixture for the fabrication of polysulfone ultrafiltration membranes: An investigation of doctor blade and slot die casting methods," Journal of Membrane Science, Vol. 614, p. 118510, Nov. 2020, https://doi.org/10.1016/j.memsci.2020.118510 
[24] J. F. Kim, J. T. Jung, H. Wang, E. Drioli, and Y. M. Lee, "1.15 effect of solvents on membrane fabrication via thermally induced phase separation (TIPS): Thermodynamic and Kinetic Perspectives," in Comprehensive Membrane Science and Engineering, Elsevier, 2017, pp. 386-417, https://doi.org/10.1016/b978-0-12-409547-2.12690-3

[25] A. Hanafia et al., "Fabrication of novel porous membrane from biobased water-soluble polymer (hydroxypropylcellulose)," Journal of Membrane Science, Vol. 526, pp. 212-220, Mar. 2017, https://doi.org/10.1016/j.memsci.2016.12.037

[26] Y. Gu and F. Jérôme, "Bio-based solvents: an emerging generation of fluids for the design of ecoefficient processes in catalysis and organic chemistry," Chemical Society Reviews, Vol. 42, No. 24, p. 9550, 2013, https://doi.org/10.1039/c3cs60241a

[27] M. A. Rasool and I. F. J. Vankelecom, "Use of $\gamma$-valerolactone and glycerol derivatives as bio-based renewable solvents for membrane preparation," Green Chemistry, Vol. 21, No. 5, pp. 1054-1064, Mar. 2019, https://doi.org/10.1039/c8gc03652g

[28] J. Sherwood et al., "Dihydrolevoglucosenone (Cyrene) as a bio-based alternative for dipolar aprotic solvents," Chem. Commun., Vol. 50, No. 68, pp. 9650-9652, 2014, https://doi.org/10.1039/c4cc04133j

[29] R. A. Milescu, C. R. Mcelroy, T. J. Farmer, P. M. Williams, M. J. Walters, and J. H. Clark, "Fabrication of PES/PVP water filtration membranes using Cyrene ${ }^{\circledR}$, a safer bio-based polar aprotic solvent," Advances in Polymer Technology, Vol. 2019, pp. 1-15, Jul. 2019, https://doi.org/10.1155/2019/9692859

[30] A. Randová et al., "A fundamental study of the physicochemical properties of Rhodiasolv®Polarclean: A promising alternative to common and hazardous solvents," Journal of Molecular Liquids, Vol. 224, pp. 1163-1171, Dec. 2016, https://doi.org/10.1016/j.molliq.2016.10.085

[31] H. H. Wang, J. T. Jung, J. F. Kim, S. Kim, E. Drioli, and Y. M. Lee, "A novel green solvent alternative for polymeric membrane preparation via nonsolvent-induced phase separation (NIPS)," Journal of Membrane Science, Vol. 574, pp. 44-54, Mar. 2019, https://doi.org/10.1016/j.memsci.2018.12.051

[32] T. Marino, E. Blasi, S. Tornaghi, E. Di Nicolò, and A. Figoli, "Polyethersulfone membranes prepared with Rhodiasolv®Polarclean as water soluble green solvent," Journal of Membrane Science, Vol. 549, pp. 192-204, Mar. 2018, https://doi.org/10.1016/j.memsci.2017.12.007

[33] H. Ajari, B. Chaouachi, F. Galiano, T. Marino, F. Russo, and A. Figoli, "A novel approach for dissolving crystalline LDPE using non-toxic solvents for membranes preparation," International Journal of Environmental Science and Technology, Vol. 16, No. 10, pp. 5375-5386, Oct. 2019, https://doi.org/10.1007/s13762-018-2123-y

[34] J. F. Kim et al., "Microporous PVDF membranes via thermally induced phase separation (TIPS) and stretching methods," Journal of Membrane Science, Vol. 509, pp. 94-104, Jul. 2016, https://doi.org/10.1016/j.memsci.2016.02.050

[35] M. R. M. Abed, S. C. Kumbharkar, A. M. Groth, and K. Li, "Ultrafiltration PVDF hollow fibre membranes with interconnected bicontinuous structures produced via a single-step phase inversion technique," Journal of Membrane Science, Vol. 407-408, pp. 145-154, Jul. 2012, https://doi.org/10.1016/j.memsci.2012.03.029

[36] J. Chang, J. Zuo, L. Zhang, G. S. O. 'Brien, and T.-S. Chung, "Using green solvent, triethyl phosphate (TEP), to fabricate highly porous PVDF hollow fiber membranes for membrane distillation," Journal of Membrane Science, Vol. 539, pp. 295-304, Oct. 2017, https://doi.org/10.1016/j.memsci.2017.06.002

[37] J.-H. Wang, Y.-H. Zhang, Y.-Y. Xu, B.-K. Zhu, and H. Xu, "Fabrication of hydrophilic and spongelike PVDF/brush-like copolymer blend membranes using triethylphosphate as solvent," Chinese Journal of Polymer Science, Vol. 32, No. 2, pp. 143-150, Feb. 2014, https://doi.org/10.1007/s10118014-1371-7

[38] J. Chang, J. Zuo, K.-J. Lu, and T.-S. Chung, "Membrane development and energy analysis of freeze desalination-vacuum membrane distillation hybrid systems powered by LNG regasification and solar energy," Desalination, Vol. 449, pp. 16-25, Jan. 2019, https://doi.org/10.1016/j.desal.2018.10.008

[39] T. Marino, S. Blefari, E. Di Nicolò, and A. Figoli, "A more sustainable membrane preparation using triethyl phosphate as solvent," Green Processing and Synthesis, Vol. 6, No. 3, pp. 295-300, Jan. 2017, https://doi.org/10.1515/gps-2016-0165

[40] S. Nejati, C. Boo, C. O. Osuji, and M. Elimelech, "Engineering flat sheet microporous PVDF films for membrane distillation," Journal of Membrane Science, Vol. 492, pp. 355-363, Oct. 2015, https://doi.org/10.1016/j.memsci.2015.05.033 
[41] H.-H. Chang, L.-K. Chang, C.-D. Yang, D.-J. Lin, and L.-P. Cheng, "Effect of solvent on the dipole rotation of poly(vinylidene fluoride) during porous membrane formation by precipitation in alcohol baths," Polymer, Vol. 115, pp. 164-175, Apr. 2017, https://doi.org/10.1016/j.polymer.2017.03.044

[42] M.-M. Tao, F. Liu, B.-R. Ma, and L.-X. Xue, "Effect of solvent power on PVDF membrane polymorphism during phase inversion," Desalination, Vol. 316, pp. 137-145, May 2013, https://doi.org/10.1016/j.desal.2013.02.005

[43] M. L. Yeow, Y. T. Liu, and K. Li, "Morphological study of poly(vinylidene fluoride) asymmetric membranes: Effects of the solvent, additive, and dope temperature," Journal of Applied Polymer Science, Vol. 92, No. 3, pp. 1782-1789, May 2004, https://doi.org/10.1002/app.20141

[44] D.-J. Lin, H.-H. Chang, T.-C. Chen, Y.-C. Lee, and L.-P. Cheng, "Formation of porous poly(vinylidene fluoride) membranes with symmetric or asymmetric morphology by immersion precipitation in the water/TEP/PVDF system," European Polymer Journal, Vol. 42, No. 7, pp. 1581-1594, Jul. 2006, https://doi.org/10.1016/j.eurpolymj.2006.01.027

[45] Q. Wang, Z. Wang, and Z. Wu, "Effects of solvent compositions on physicochemical properties and anti-fouling ability of PVDF microfiltration membranes for wastewater treatment," Desalination, Vol. 297, pp. 79-86, Jul. 2012, https://doi.org/10.1016/j.desal.2012.04.020

[46] T. Marino, F. Russo, and A. Figoli, "The formation of polyvinylidene fluoride membranes with tailored properties via vapour/non-solvent induced phase separation," Membranes, Vol. 8, No. 3, p. 71, Sep. 2018, https://doi.org/10.3390/membranes8030071

[47] S. Fadhil et al., "Novel PVDF-HFP flat sheet membranes prepared by triethyl phosphate (TEP) solvent for direct contact membrane distillation," Chemical Engineering and Processing: Process Intensification, Vol. 102, pp. 16-26, Apr. 2016, https://doi.org/10.1016/j.cep.2016.01.007

[48] Q. F. Alsalhy, H. A. Salih, S. Simone, M. Zablouk, E. Drioli, and A. Figoli, "Poly(ether sulfone) (PES) hollow-fiber membranes prepared from various spinning parameters," Desalination, Vol. 345, pp. $21-$ 35, Jul. 2014, https://doi.org/10.1016/j.desal.2014.04.029

[49] A. Moriya, T. Maruyama, Y. Ohmukai, T. Sotani, and H. Matsuyama, "Preparation of poly(lactic acid) hollow fiber membranes via phase separation methods," Journal of Membrane Science, Vol. 342, No. 1-2, pp. 307-312, Oct. 2009, https://doi.org/10.1016/j.memsci.2009.07.005

[50] D. Kim, N. Moreno, and S. P. Nunes, "Fabrication of polyacrylonitrile hollow fiber membranes from ionic liquid solutions," Polymer Chemistry, Vol. 7, No. 1, pp. 113-124, 2016, https://doi.org/10.1039/c5py01344e

[51] N. Evenepoel, S. Wen, M. Tilahun Tsehaye, and B. van der Bruggen, "Potential of DMSO as greener solvent for PES ultra - and nanofiltration membrane preparation," Journal of Applied Polymer Science, Vol. 135, No. 28, p. 46494, Jul. 2018, https://doi.org/10.1002/app.46494

[52] I. Sadeghi, A. Aroujalian, A. Raisi, B. Dabir, and M. Fathizadeh, "Surface modification of polyethersulfone ultrafiltration membranes by corona air plasma for separation of oil/water emulsions," Journal of Membrane Science, Vol. 430, pp. 24-36, Mar. 2013, https://doi.org/10.1016/j.memsci.2012.11.051

[53] M. T. Tsehaye, J. Wang, J. Zhu, S. Velizarov, and B. van der Bruggen, "Development and characterization of polyethersulfone-based nanofiltration membrane with stability to hydrogen peroxide," Journal of Membrane Science, Vol. 550, pp. 462-469, Mar. 2018, https://doi.org/10.1016/j.memsci.2018.01.022

[54] Y. L. Thuyavan, N. Anantharaman, G. Arthanareeswaran, and A. F. Ismail, "Impact of solvents and process conditions on the formation of polyethersulfone membranes and its fouling behavior in lake water filtration," Journal of Chemical Technology and Biotechnology, Vol. 91, No. 10, pp. 2568-2581, Oct. 2016, https://doi.org/10.1002/jctb.4846

[55] T. Marino, F. Galiano, S. Simone, and A. Figoli, "DMSO EVOL TM as novel non-toxic solvent for polyethersulfone membrane preparation," Environmental Science and Pollution Research, Vol. 26, No. 15, pp. 14774-14785, May 2019, https://doi.org/10.1007/s11356-018-3575-9

[56] G. Arthanareeswaran and V. M. Starov, "Effect of solvents on performance of polyethersulfone ultrafiltration membranes: Investigation of metal ion separations," Desalination, Vol. 267, No. 1, pp. 57-63, Feb. 2011, https://doi.org/10.1016/j.desal.2010.09.006

[57] B. Wang, J. Ji, C. Chen, and K. Li, "Porous membranes prepared by a combined crystallisation and diffusion (CCD) method: Study on formation mechanisms," Journal of Membrane Science, Vol. 548, pp. 136-148, Feb. 2018, https://doi.org/10.1016/j.memsci.2017.11.005

[58] D. Y. Xing, W. Y. Dong, and T.-S. Chung, "Effects of different ionic liquids as green solvents on the formation and ultrafiltration performance of CA hollow fiber membranes," Industrial and Engineering 
Chemistry Research, Vol. 55, No. 27, pp. 7505-7513, Jul. 2016, https://doi.org/10.1021/acs.iecr.6b01603

[59] D. Y. Xing, N. Peng, and T.-S. Chung, "Investigation of unique interactions between cellulose acetate and ionic liquid [EMIM]SCN, and their influences on hollow fiber ultrafiltration membranes," Journal of Membrane Science, Vol. 380, No. 1-2, pp. 87-97, Sep. 2011, https://doi.org/10.1016/j.memsci.2011.06.032

[60] D. Kim, O. R. Salazar, and S. P. Nunes, "Membrane manufacture for peptide separation," Green Chemistry, Vol. 18, No. 19, pp. 5151-5159, 2016, https://doi.org/10.1039/c6gc01259k

[61] D. Kim, H. Vovusha, U. Schwingenschlögl, and S. P. Nunes, "Polyethersulfone flat sheet and hollow fiber membranes from solutions in ionic liquids," Journal of Membrane Science, Vol. 539, pp. 161171, Oct. 2017, https://doi.org/10.1016/j.memsci.2017.06.001

[62] L. Wu and J. Sun, "An improved process for polyvinylidene fluoride membrane preparation by using a water soluble diluent via thermally induced phase separation technique," Materials and Design, Vol. 86, pp. 204-214, Dec. 2015, https://doi.org/10.1016/j.matdes.2015.07.053

[63] S. Rajabzadeh, T. Maruyama, T. Sotani, and H. Matsuyama, "Preparation of PVDF hollow fiber membrane from a ternary polymer/solvent/nonsolvent system via thermally induced phase separation (TIPS) method," Separation and Purification Technology, Vol. 63, No. 2, pp. 415-423, Oct. 2008, https://doi.org/10.1016/j.seppur.2008.05.027

[64] Z. Cui et al., "Tailoring novel fibrillar morphologies in poly(vinylidene fluoride) membranes using a low toxic triethylene glycol diacetate (TEGDA) diluent," Journal of Membrane Science, Vol. 473, pp. 128-136, Jan. 2015, https://doi.org/10.1016/j.memsci.2014.09.019

[65] S.-I. Sawada, C. Ursino, F. Galiano, S. Simone, E. Drioli, and A. Figoli, "Effect of citrate-based nontoxic solvents on poly(vinylidene fluoride) membrane preparation via thermally induced phase separation," Journal of Membrane Science, Vol. 493, pp. 232-242, Nov. 2015, https://doi.org/10.1016/j.memsci.2015.07.003

[66] J. T. Jung et al., "Tailoring nonsolvent-thermally induced phase separation (N-TIPS) effect using triple spinneret to fabricate high performance PVDF hollow fiber membranes," Journal of Membrane Science, Vol. 559, pp. 117-126, Aug. 2018, https://doi.org/10.1016/j.memsci.2018.04.054

[67] N. T. Hassankiadeh et al., "Microporous poly(vinylidene fluoride) hollow fiber membranes fabricated with PolarClean as water-soluble green diluent and additives," Journal of Membrane Science, Vol. 479, pp. 204-212, Apr. 2015, https://doi.org/10.1016/j.memsci.2015.01.031

[68] M. A. Rasool, C. van Goethem, and I. F. J. Vankelecom, "Green preparation process using methyl lactate for cellulose-acetate-based nanofiltration membranes," Separation and Purification Technology, Vol. 232, p. 115903, Feb. 2020, https://doi.org/10.1016/j.seppur.2019.115903

[69] J. T. Jung, J. F. Kim, H. H. Wang, E. Di Nicolo, E. Drioli, and Y. M. Lee, "Understanding the nonsolvent induced phase separation (NIPS) effect during the fabrication of microporous PVDF membranes via thermally induced phase separation (TIPS)," Journal of Membrane Science, Vol. 514, pp. 250-263, Sep. 2016, https://doi.org/10.1016/j.memsci.2016.04.069

[70] Z. Cui et al., "Wide liquid-liquid phase separation region enhancing tensile strength of poly(vinylidene fluoride) membranes via TIPS method with a new diluent," Polymer, Vol. 141, pp. 46-53, Apr. 2018, https://doi.org/10.1016/j.polymer.2018.02.054

[71] Y. Su, C. Chen, Y. Li, and J. Li, "PVDF membrane formation via thermally induced phase separation," Journal of Macromolecular Science, Part A, Vol. 44, No. 1, pp. 99-104, Jan. 2007, https://doi.org/10.1080/10601320601044575

[72] D. S. Lakshmi et al., "Preparation of polymeric membranes and microcapsules using an ionic liquid as morphology control additive," Macromolecular Symposia, Vol. 357, No. 1, pp. 159-167, Nov. 2015, https://doi.org/10.1002/masy.201400214

[73] C. S. M. Pereira, V. M. T. M. Silva, and A. E. Rodrigues, "Ethyl lactate as a solvent: properties, applications and production processes - a review," Green Chemistry, Vol. 13, No. 10, p. 2658, 2011, https://doi.org/10.1039/c1gc15523g

[74] G. Falca, V.-E. Musteata, A. R. Behzad, S. Chisca, and S. P. Nunes, "Cellulose hollow fibers for organic resistant nanofiltration,” Journal of Membrane Science, Vol. 586, pp. 151-161, Sep. 2019, https://doi.org/10.1016/j.memsci.2019.05.009

[75] F. M. Sukma and P. Z. Çulfaz-Emecen, "Cellulose membranes for organic solvent nanofiltration," Journal of Membrane Science, Vol. 545, pp. 329-336, Jan. 2018, https://doi.org/10.1016/j.memsci.2017.09.080 


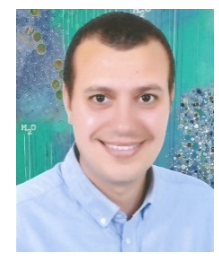

Alaa Mohamed obtained his Ph.D. from Cairo University, Egypt in 2014 and subsequently continued as a Postdoctoral Fellow in KTH Royal Institute of Technology, Sweden from (2014-2015). His work in KTH mainly focused on the synthesis of nanocomposite and nanofiber membrane for photocatalytic technology that has attracted extensive attention for degradation and removal of organic contaminants, heavy metals and hazardous microorganisms from drinking water under ultraviolet and visible light irradiation. In 2018, he started working as a Postdoctoral in Karlsruhe Institute of Technology (KIT), Germany, on developing novel membrane materials for micropollutant removal from water and controllable contaminant removal with longer membrane lifetime and reduced cost, understand transport and fouling phenomena and design new processes for water treatment applications. His research interest are designing and developing novel nanomaterials, (SURMOFs) and metal-organic frameworks (MOFs) with desired characteristics; developing highly efficient photocatalyst, membrane filtration for water treatment application, gas separation, batteries, and fuel cell applications.

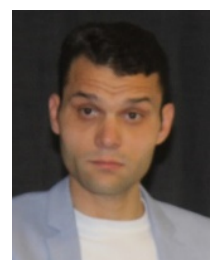

Samy Yousef has completed his Ph.D. in mechanical engineering, Cairo University, Egypt. After that, he obtained postdoctoral studies from Messina University, Italy (one year), and University of Technology, Lithuania (two years). Since 2018, He is Associate Professor, senior researcher at Faculty of Mechanical Engineering and Design, Kaunas University of Technology. He has published more than 53 papers (Scopus) in reputed journals with total impact factor $>200$ and $\mathrm{H}$ index (17). During the last four years, Dr. Yousef has achieved several promising results in materials recovery from different wastes such as WEEE, packages, solar cells, textile, and banknote waste, etc. then reprocessing of extracting metals into high added value products and adapting laboratory technology for industrial scale and Circular Economy principles. Also, he participated in developing many sustainable energy conversion strategies for textile waste, clothes dryer, plastic waste, endof-life cotton banknotes into energy products using pyrolysis technology 